\title{
DESCRIPTIONS OF NEW SPECIES OF AUSTRALIAN RHOPALOCERA.
}

By G. A. Waterhouse, B.Sc., B.E.

(Plate i.)

OGYRIS IANTHIS, sp.nov.

(Plate i., figs. 1-4.)

๙. $36 \mathrm{~mm}$. Head fuscous; palpi fuscous-grey; antennæ fuscous, becoming fuscous-red at their distal ends, slightly lighter on the underside and faintly annulated with white; thorax black, with long grey hairs at the sides.

Abdomen.- Upperside purplish-fuscous, underside fuscous-grey.

Upperside.-Light silvery electric blue margined with blackishfuscous.

Anterior wing.-A band bounded by the costa and subcostal vein blackish-fuscous, beginning from the base of the wing and extending to the apex, where it is widest, thence along the termen or outer margin gradually decreasing in width until the inner margin or dorsum is reached, where the band ends. The remainder of the wing is light electric blue, which changes when the insect is moved, as in the case of the South American Morphos. The veins are lightly coloured with black, the one bounding the distal end of cell being markedly so.

Posterior wing.--Colours similarly placed to anterior wing. As before, a blackish-fuscous band beginning at the base, extending along the costa to the apex; here the band narrows considerably along the termen, and is irregular, extending further into the wing between the veins, and being prolonged outwards along the veins, thus giving the termen a slightly serrated appearance. 
Abdominal groove grey, becoming darker near the anal angle, speckled with light blue. The remainder of wing light electric blue.

Underside.-Anterior wing with the costal margin from base to apex, and the termen $\frac{3}{4}$ from apex lilac-fuscous, widest at apex. Cell fuscous, the dorsum fuscous-grey. Markings as followsin the cell close to the base an oval fuscous spot faintly margined with white ; in middle of cell a large oblong black spot extending across the cell, margined with pale electric blue; just at the termination of cell another oblong black spot margined with electric blue. Below each of the foregoing spots is a blackishfuscous blotch without a border and outside the cell. At $\frac{3}{4}$ of the distance from base is a series of five small fuscous-black spots arranged parallel to the termen, all but the lowest being margined with white; a faint irregular fuscous band situated beyond and parallel to these last.

Posterior wing.-General colour lilac-fuscous, darker fuscous along the termen, a dark fuscous blotch at anal angle. The whole wing is marked with faint fuscous marks arranged concentrically with the margins in one or more rows; these last are ill defined and variable in different specimens. Cilia fuscous.

o $37 \mathrm{~mm}$. Head, palpi, antennæ, thorax and abdomen as in $\hat{\delta}$.

Upperside.-Pale orange-yellow, very broadly margined with dark fuscous-black.

Anterior wing. - The dark bands as in $\hat{\delta}$, but much broader. extending along the costa halfway into the cell, much broader along the termen and tornus or lower angle, and extending along the greater part of the dorsum, the base fuscous-black. The remainder of the wing orange-yellow, except the distal end of cell which is fuscous-black.

Posterior wing.-Fuscous-black, with a very faint orange colouring just below the cell towards the anal angle, the abdominal groove fuscous-grey. Dorsum prolonged outwards along the veins.

Underside.-Anterior wing with the base, costal margin, and termen to $\frac{3}{4}$ from apex lilac-fuscous. Tornus and $\frac{1}{2}$ the dorsum 
fuscous-grey, the rest of the wing orange-yellow, with the markings as follows - the oval fuscous spot margined with white near base of cell, a blackish spot margined with electric blue in the middle of cell, and a similar one at end of cell as in $\hat{\jmath}$. The blotches below the cell are not shown. The first series of spots is represented by three blue-margined black spots, and the outer series is faintly visible.

Posterior wing. - Base of wing and $\frac{1}{4}$ from base lilac-fuscous, faintly bordered with white from middle of cell to dorsum, a whitish suffusion on dorsum near anal angle. The rest of wing fuscous, mottled with fuscous-black, termen within the cilia marked with a black line, fuscous-black at termination of the veins, slightly lighter between them.

Loc._Como, near Sydney, N.S.W.; seven specimens ( 76 ; 이, which is probably undersized); in February and March. Types in author's collection. The insects were all caught flying round the tops of small Eucalypts, about 16 feet from the ground.

The sexes of this insect correspond to one another in the same way as do those of $O$. abrota. The purple of the upper side of

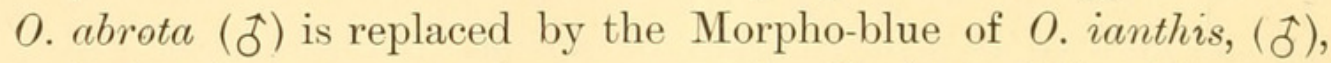
and the dark margin is narrower in O. abrota $(\hat{\delta})$. The pale round spot of O.abrota (Q) is represented by an oval orange-yellow in $O$. ianthis (q). The termen of the posterior wing is more serrated in O. abrota. The underside of these two species is quite different.

The upper surface of $O$. ianthis (j) in colour is allied to $O$. amaryllis ( $\hat{\zeta})$, but the latter has narrower dark borders.

The underside is much nearer to that of $O$. otanes than any of the other species, but is generally darker in colour.

Hesperilla Mastersi, sp. nov.

$$
\text { (Plate i., figs. 5-8.) }
$$

o $40 \mathrm{~mm}$. Head fuscous; palpi yellowish-white; antennæ black above, fuscous-red at the distal end below, annulated with 
white more conspicuous below. Thorax black; abdomen black above, with alternate bands of fuscous and ochreous on each body segment below.

Upper side.-Anterior wing with costa nearly straight, apex rather pointed; termen oblique. Colour fuscous, with a faint ochreous suffusion over the wing, more marked close to the base. Five light ochreous-yellow hyaline spots arranged as followsthree small, adjacent, arranged in a transverse series beneath the costa towards the apex; one large, trapezoidal, occupying distal half of cell; the last small, situated obliquely below the end of cell; the black oblique transverse bar characteristic of the male commencing between these last spots, and reaching the middle of dorsum. Cilia on termen fuscous at terminations of veins, ochreous-fuscous between them.

Posterior wing.-Anal angle rather sharply rounded. Colour dark blackish-fuscous with one large opaque ochreous spot, broadest towards the termen, occupying the centre quarter of the wing, a few long ochreous hairs towards the base. Cilia long, fuscous at terminations of the veins, otherwise deep ochreous.

Underside.-Anterior wing with hyaline spots as above, a pale opaque yellow spot below the lowest spot visible on upperside. Costa cream at base, then fuscous, with four cream marks towards the apex; basal third of wing blackish-fuscous, apical third cinnamon-fuscous, with a large subquadrate cream spot divided by a fuscous vein, and two small cream spots, one above and one below this, all towards the termen. Dorsum pale yellowish, widest near the middle of the wing. Termen marked by a pale cream border, interrupted by the veins, which are fuscous; cilia somewhat lighter than on the upperside.

Posterior wing.--General pattern similar to the apical third of the anterior wing. Base and basal half of costa cream; from apex extending across the wing to the middle of dorsum a wide cream band interrupted in the centre of the wing, and on the abdominal fold by reddish-fuscous; in this band close to apex a single circular black spot. Below this another cream band, narrower 
and more interrupted towards anal angle. The rest of wing reddish-fuscous, with the abdominal fold fuscous except at the middle of dorsum, which is cream. Termen marked by an interrupted cream line as in anterior wing. Cilia long, pale fuscous-ochreous, with four fuscous patches at terminations of veins. Legs reddish-fuscous.

ㅇ $46 \mathrm{~mm}$. Head, palpi, antennæ and legs as in $\hat{\delta}$; thorax dark fuscous, with long pale yellowish-fuscous hairs at sides. Abdomen fuscous, with the segments marked by pale yellowish-ochreous. above and cream in median line below, with bands of fuscous and cream at sides.

Upperside as in $\hat{\delta}$, with the spots somewhat larger.

Anterior wing fuscous, with the five hyaline spots well marked and somewhat more ochreous; a sixth ochreous-yellow hyaline spot, subquadrate, below the fifth, and below this again an elongated opaque ochreous spot reaching nearly to the dorsum; at $\frac{1}{3}$ near the dorsum a small ochreous oval blotch, with short ochreous hairs extending from it to the base. Costa only faintly suffused with ochreous. The shape of the wing more rounded than in $\hat{\jmath}$. Cilia as in $\hat{\delta}$.

Posterior wing.-Much more rounded than in $\delta$, especially at anal angle. The central ochreous spot much larger. The rest of the wing blackish-fuscous, with long ochreous hairs extending from the central spot to base, and along abdominal fold. Cilia well marked and long, alternately fuscous and ochreous.

Underside. - The general pattern as in $\hat{\delta}$.

Anterior wing.-The six hyaline spots showing the sixth in the same position as the opaque spot of $\hat{\delta}$; the blackish-fuscous extending further towards the apex, otherwise as in $\delta$.

Posterior wing.-With the exception of the more rounded shape of the wing, as in $\delta$.

Loc._Mount Kembla, Illawarra, N.S.W. (Mr A. G. Hamilton); Clifton, N.S.W. (G. A. Waterhouse, January, 1897).

Two specimens in the author's collection $(\hat{\delta}, q)$; one in the Macleay Museum (q); and one in the Australian Museum. 
This species belongs to the $H$. picta and $H$. ornata types of Hesperilla. It is closest to $H$. picta, Leach, but differs from it in having lighter-coloured forewings, fewer spots on the forewing of the male, and the central ochreous spot of the hindwing much brighter and larger. On the undersurface they are similar in having the apical third of the forewing and the whole hindwing of the same general pattern, but these general patterns are totally distinct, and constitute the most marked difference between the two species. The pattern of $I$. picta is fairly sharply defined, while that of $H$. Mastersi is mottled, and not at all well defined.

I have to record the presence in New South Wales of Ogyris genoveva, Hew., and $O$. olane, Hew. Of the former I caught several males flying round the tops of Eucalypts, about 25 feet from the ground, at Como during March. The latter was caught by Mr. N. W. Hansard at Lawson, Blue Mts., in January.

\section{EXPLANATION OF PLATE.}

Ogyris ianthis, $\delta$.

Fig. 1.-Upperside.

Fig. 2.--Underside.

$$
\text { O. ianthis, } q \text {. }
$$

Fig. 3.-Upperside.

Fig. 4.-Underside.

Hesperilla Mastersi, ठ

Fig. 5.-Upperside.

Fig. 6.-Underside.

$$
\text { H. Mastersi, } \subsetneq \text {. }
$$

Fig. 7.-Upperside.

Fig. 8.-Underside. 


\section{$2 \mathrm{BHL}$ Biodiversity Heritage Library}

Waterhouse, Gustavus A. 1900. "Descriptions of new species of Australian Rhopalocera." Proceedings of the Linnean Society of New South Wales 25, 52-57. https://doi.org/10.5962/bhl.part.12146.

View This Item Online: https://www.biodiversitylibrary.org/item/30484

DOI: https://doi.org/10.5962/bhl.part.12146

Permalink: https://www.biodiversitylibrary.org/partpdf/12146

\section{Holding Institution}

MBLWHOI Library

\section{Sponsored by}

MBLWHOI Library

\section{Copyright \& Reuse}

Copyright Status: NOT_IN_COPYRIGHT

This document was created from content at the Biodiversity Heritage Library, the world's largest open access digital library for biodiversity literature and archives. Visit BHL at https://www.biodiversitylibrary.org. 